\title{
Appeasing Pheromones against Bovine Respiratory Complex and Modulation of Immune Transcript Expressions
}

\author{
Caroline Hervet ${ }^{1}$, Justine Boullier ${ }^{1,2}$, Marlène Guiadeur ${ }^{2}$, Léa Michel ${ }^{3}$, Laure Brun-Lafleur ${ }^{4}$, Anne Aupiais ${ }^{4}$, \\ Jianzhong Zhu ${ }^{5,6} \mathbb{D}^{\mathbb{D}}$, Béatrice Mounaix ${ }^{4}$, François Meurens ${ }^{1,7, *,+}$, Fanny Renois ${ }^{1,+}$ and Sébastien Assié ${ }^{1,+(\mathbb{C}}$ \\ 1 BIOEPAR, INRAE, Oniris, 44307 Nantes, France; caroline.hervet@inrae.fr (C.H.); \\ justine.boullier19@hotmail.fr (J.B.); fanny.renois-meurens@oniris-nantes.fr (F.R.); \\ sebastien.assie@oniris-nantes.fr (S.A.) \\ 2 Institut de l'Élevage, 14310 Villers-Bocage, France; Marlene.guiadeur@idele.fr \\ 3 TERRENA Innovation, La Noëlle, 20199 Ancenis, France; lmichel@terrena.fr \\ 4 Institut de l’Élevage, 35652 Le Rheu, France; laure.brun-lafleur@idele.fr (L.B.-L.); anne.aupiais@idele.fr (A.A.); \\ beatrice.mounaix@idele.fr (B.M.) \\ 5 College of Veterinary Medicine, Comparative Medicine Research Institute, Yangzhou University, \\ Yangzhou 225009, China; jzzhu@yzu.edu.cn \\ 6 Joint International Research Laboratory of Agriculture and Agri-Product Safety, Yangzhou 225009, China \\ 7 Department of Veterinary Microbiology and Immunology, Western College of Veterinary Medicine, \\ Saskatoon, SK S7N5E3, Canada \\ * Correspondence: francois.meurens@inrae.fr; Tel.: +33-240-68-77-02 \\ + The authors contribute equally.
}

check for

updates

Citation: Hervet, C.; Boullier, J.;

Guiadeur, M.; Michel, L.;

Brun-Lafleur, L.; Aupiais, A.; Zhu, J.;

Mounaix, B.; Meurens, F.; Renois, F.; et al. Appeasing Pheromones against Bovine Respiratory Complex and Modulation of Immune Transcript Expressions. Animals 2021, 11, 1545. https://doi.org/10.3390/ani11061545

Academic Editor: Natalia Elguezabal

Received: 6 May 2021

Accepted: 24 May 2021

Published: 25 May 2021

Publisher's Note: MDPI stays neutral with regard to jurisdictional claims in published maps and institutional affiliations.

Copyright: (c) 2021 by the authors. Licensee MDPI, Basel, Switzerland. This article is an open access article distributed under the terms and conditions of the Creative Commons Attribution (CC BY) license (https:// creativecommons.org/licenses/by/ $4.0 /)$.
Simple Summary: Bovine respiratory complex is still a major issue in bovine feedlots. Most of the time, antimicrobial molecules are used to manage these diseases with deleterious consequences for microbiota and the emergence and shedding of resistant bacteria. To improve bovine health and reduce the risk for cattle to develop respiratory infections, alternative molecules such as appeasing pheromones have been developed. In this study, we tested bovine appeasing pheromones in young bulls. We treated them at the beginning of the fattening period and measured zootechnical and health parameters over several weeks. We identified dual effects of pheromone treatment. Indeed, more respiratory clinical signs were observed in bulls who received the pheromone treatment on Day 8 than in bulls who did not, while it was the opposite on Day 30. Regarding the potential mechanism to explain the effect of the pheromone treatment, we identified an increased expression of transcripts associated with the expression of immune molecules involved in the recruitment of cells important to manage pathogens. Our study suggests a positive final effect of appeasing pheromones and opens the doors for future studies in beef cattle.

Abstract: Bovine respiratory disease is still a major concern and has major economic impact. Another consequence of respiratory infections is the use of antimicrobial molecules to control bacterial pathogens. This can participate in the emergence and shedding of antimicrobial resistance that can threaten animal as well as human health. Appeasing pheromones with their capacity to reduce stress and thus their ability to preserve the functions of the immune system have been proposed to reduce the use of antimicrobial substances. In this study, we assessed the effect of appeasing pheromone administration on bovine health and performance during the fattening period. Zootechnical and health parameters and whole blood immune transcript expressions were measured over four weeks in bulls to determine the effect of the pheromone. We observed increased clinical signs on Day 8 (D8) and decreased clinical signs on D30 in bulls who received the pheromone and a higher expression of interleukin 8 transcripts in this group than in the control group on D8. Our results are overall in line with previous reports in livestock species. Further studies are needed to shed more light on the effect of appeasing pheromones and decipher their exact mechanisms of action.

Keywords: appeasing pheromone; bovine; respiratory infections; immune response; average daily gain 


\section{Introduction}

Bovine respiratory disease (BRD) complex remains a major cause of morbidity and mortality in bovine feedlots with major economic consequences [1]. Multiple pathogens, including various bacteria and viruses, and several host and environment factors such as air quality are involved in the pathogenesis of BRD complex [2-5]. To control bacterial infections, antimicrobial molecules are commonly used before (methaphylaxis) or after the detection of various clinical signs. These antibacterial treatments have major consequences not only on bovine respiratory and gut microbiota and pathogens but also on the shedding of resistant bacteria and resistance determinants into the surrounding environment [6-8]. This constitutes a serious health issue for animals and humans. Among the multiple factors involved in the pathogenesis of $\mathrm{BRD}$, the stress has a determinant role [5,9]. It has been shown that stress is increased during the fattening period of young bulls for several reasons, including a recent weaning and the transportation of young bulls and their mixing in a new confined environment when they are coming from different farms [5,10-14]. Within a few days, multiple periods of stress show an impact on immune defense mechanisms of young bovine with consequences on the onset and persistence of respiratory infectious disorders [9,15-17].

To prevent the onset of respiratory infections during the fattening period of young bulls, vaccinations targeting the main pathogens can also be used $[2,18]$. Currently, vaccination is carried out when the young are gathering. However, this is quite late to enable a good protection at the beginning of the fattening period. New breeding management practices to limit the impact of stress on the immune system of young bovines (batches of bulls coming from a same farm, reduced transport time, etc.) could be considered. However, the implementation of these new practices could be challenging for the stakeholders. An alternative to reduce the impact of the stress could be the use in young animals of appeasing pheromones, as demonstrated in several species [19-21]. The production of these hormones during nursing exists in all mammals including bovine. In cows, there is a specific area between the two mammary chains [22]. Appeasing pheromones are produced by sebaceous glands of the sulcus. Synthetic analogs of the bovine appeasing hormone have been developed based on a mixture of fatty acids. They are similar to the pheromone produced by the dam at calving [23].

To the best of our knowledge, the effect of appeasing pheromone on bovine performance and disease incidence has been assessed in a limited number of studies [22,24-26]. Positive effects including increased performance and improved early detection of BRD signs were reported in dairy cattle as well as beef cattle.

Thus, in a global context of antimicrobial molecules use reduction, we decided to assess the effect of bovine appeasing pheromone on stress, the development of respiratory disorders, and whole blood immune transcript expression in young bulls over the four first weeks of fattening. Interesting observations were collected, showing an effect of the pheromones on bovine health and thus contributing to a better knowledge of this alternative tool.

\section{Materials and Methods}

\subsection{Study Facilities}

The study was carried out in four young bull fattening units in western France. The basic husbandry management of these fattening units is representative of standard management used in this area. In western France, 5-10-month-old young bulls are weaned and immediately transported to a sorting facility to be sorted by breed and body weight, forming new batches that fulfill the orders of the fatteners. The newly formed batches were transported to the fattening units for the entire fattening period. In the different fattening units, bulls from different suckler farms were mixed according to regular French farm practices. During the fattening period, young bulls were reared in barns composed of pens of 5-20 animals for a space allowance of 3.5-5.5 $\mathrm{m}^{2} /$ bull. Young bulls were commonly fed with a complete diet composed of corn or grass silage and a mixture of cereals and urea. 


\subsection{Animals}

The 265 animals utilized in the study were young Charolais bulls aged 317 days (d) ( $\pm 51.8 \mathrm{~d})$ at arrival at the sorting facility between January and March 2018 (Table 1). The animals came from multiple suckler farms. On arrival at the sorting facility, they were moved through a chute for a series of treatments. They were treated with doramectin anthelmintic (Dectomax, Elanco, Sèvres, France), vaccinated once with a vaccine containing modified-live bovine viral diarrhea virus (BVDV) and bovine respiratory syncytial virus (BRSV) (Rispoval RS-BVD, Pfizer, Paris, France), and then weighed. The average weight of the 265 animals was $366.7 \mathrm{~kg}$ ( $\pm 30.8 \mathrm{~kg})$. The farm bulls were housed and maintained in compliance with the French Ministry of Agriculture and Fishing standards for the protection of animals.

Table 1. Distribution of young bulls (YB) by batches and study Group ("pheromone" or "control").

\begin{tabular}{|c|c|c|c|c|c|c|c|c|c|c|c|c|c|c|}
\hline & & \multirow[b]{2}{*}{$\mathbf{Y B}^{1}$} & \multirow[b]{2}{*}{ Age } & \multirow{2}{*}{$\begin{array}{c}\text { Body } \\
\text { Weight }\end{array}$} & \multicolumn{5}{|c|}{ Pheromone Group } & \multicolumn{5}{|c|}{ Control Group } \\
\hline & & & & & Batches & YB & $\begin{array}{l}\text { YB per } \\
\text { Batches }\end{array}$ & Age & $\begin{array}{c}\text { Body } \\
\text { Weight }\end{array}$ & Batches & YB & $\begin{array}{l}\text { YB per } \\
\text { Batches }\end{array}$ & Age & $\begin{array}{c}\text { Body } \\
\text { Weight }\end{array}$ \\
\hline \multirow{4}{*}{$\begin{array}{l}\text { Fattening } \\
\text { unit }\end{array}$} & 1 & 60 & $\begin{array}{c}338 \\
( \pm 51)\end{array}$ & $\begin{array}{c}391 \\
( \pm 27)\end{array}$ & 3 & 36 & 12 & $\begin{array}{c}343 \\
( \pm 55)\end{array}$ & $\begin{array}{c}391 \\
( \pm 31)\end{array}$ & 2 & 24 & 12 & $\begin{array}{c}335 \\
( \pm 48)\end{array}$ & $\begin{array}{c}390 \\
( \pm 21)\end{array}$ \\
\hline & 2 & 90 & $\begin{array}{c}324 \\
( \pm 43)\end{array}$ & $\begin{array}{c}377 \\
( \pm 22)\end{array}$ & 4 & 60 & 15 & $\begin{array}{c}319 \\
( \pm 45)\end{array}$ & $\begin{array}{c}377 \\
( \pm 25)\end{array}$ & 2 & 30 & 15 & $\begin{array}{c}328 \\
( \pm 37)\end{array}$ & $\begin{array}{c}378 \\
( \pm 14)\end{array}$ \\
\hline & 3 & 60 & $\begin{array}{c}338 \\
( \pm 47)\end{array}$ & $\begin{array}{c}371 \\
( \pm 25)\end{array}$ & 2 & 30 & 15 & $\begin{array}{c}339 \\
( \pm 52)\end{array}$ & $\begin{array}{c}382 \\
( \pm 26)\end{array}$ & 2 & 30 & 15 & $\begin{array}{c}337 \\
( \pm 39)\end{array}$ & $\begin{array}{c}361 \\
( \pm 18)\end{array}$ \\
\hline & 4 & 55 & $\begin{array}{c}261 \\
( \pm 49)\end{array}$ & $\begin{array}{c}323 \\
( \pm 20)\end{array}$ & 5 & 33 & $\begin{array}{c}3 \times 6 \\
1 \times 5 \\
1 \times 10\end{array}$ & $\begin{array}{c}246 \\
( \pm 52)\end{array}$ & $\begin{array}{c}316 \\
( \pm 15)\end{array}$ & 3 & 22 & $\begin{array}{c}1 \times 10 \\
2 \times 6\end{array}$ & $\begin{array}{c}284 \\
( \pm 37)\end{array}$ & $\begin{array}{c}336 \\
( \pm 17)\end{array}$ \\
\hline Total & & 265 & $\begin{array}{c}320 \\
( \pm 54)\end{array}$ & $\begin{array}{c}370 \\
( \pm 32)\end{array}$ & 14 & 159 & & $\begin{array}{c}312 \\
( \pm 58)\end{array}$ & $\begin{array}{c}372 \\
( \pm 36)\end{array}$ & 9 & 106 & & $\begin{array}{c}325 \\
( \pm 45)\end{array}$ & $\begin{array}{c}368 \\
( \pm 26)\end{array}$ \\
\hline
\end{tabular}

${ }^{1}$ YB, Young Bull. The age is in days and the body weight in kilograms.

\subsection{Batches Constitution and Pheromone Administration}

Animals were sorted by weight, conformation, and farms of origin to form 23 homogeneous batches of 5-15 animals (Table 1). Two treatment groups were then randomly constituted. The pheromone group consisted of 159 young bulls in 14 batches and the control group consisted of 106 young bulls in 9 batches. For a given fattening unit, batches of pheromone and control group had comparable mean weight and included young bulls with similar conformations and from the same farms of origin.

\subsection{Pheromone Administration}

Before leaving the sorting facility, animals were moved again through a chute. Five milliliters of SecureCattle ${ }^{\circledR}$ (Signs-Irsea Group, Apt, France) (pheromone group) or $5 \mathrm{~mL}$ of transcutol (Diethylene glycol monoethyl ether-Gattefossé, Saint-Priest, France) (control group), a high-purity solvent and powerful solubilizer associated with skin penetration enhancement in topical dosage forms, were deposited on the coat in the middle of the forehead-at the crossing point of two imaginary lines drawn between the eyes and the center of the base of the opposite horns. An Injecmaster ${ }^{\circledR}$ automatic syringe without any needle was used to perform the pour-on administration (Génia, St. Hilaire de Chaléons, France). From there, contacts between young bulls from pheromone and control groups were prevented using an empty pen between groups in some fattening units and double fences with empty spaces between fences in the other groups.

\subsection{Clinical Assessments}

On Day 8 (D8) and D30, a veterinarian performed a visual examination for detection of BRD clinical signs (increase in respiratory rate, dyspnea, cough, nasal or ocular discharge, and depression). A diagnosis of BRD was established when the animal displayed: (i) nasal or ocular discharge or cough; and (ii) an increase in respiratory rate or depression. No 
clinical assessment was performed on D0 since BRD usually develop after the arrival at the fattening unit.

\subsection{Activity and Behavioral Observations}

Two observers blindly recorded activities, behaviors, and stereotypies (Table 2) on D0, D8, and D30 during a $6 \mathrm{~h}$ observation period. Both observers looked at the pheromone and placebo young bulls. They used instantaneous sampling of individual young bulls in each group using 5 min scan sampling. Data were recorded 48 times per day each, during $61 \mathrm{~h}$ observation periods from 9 a.m. to noon and from 2 p.m. to 5 p.m.

Table 2. List of activities, behaviors, and stereotypies observed and their respective description.

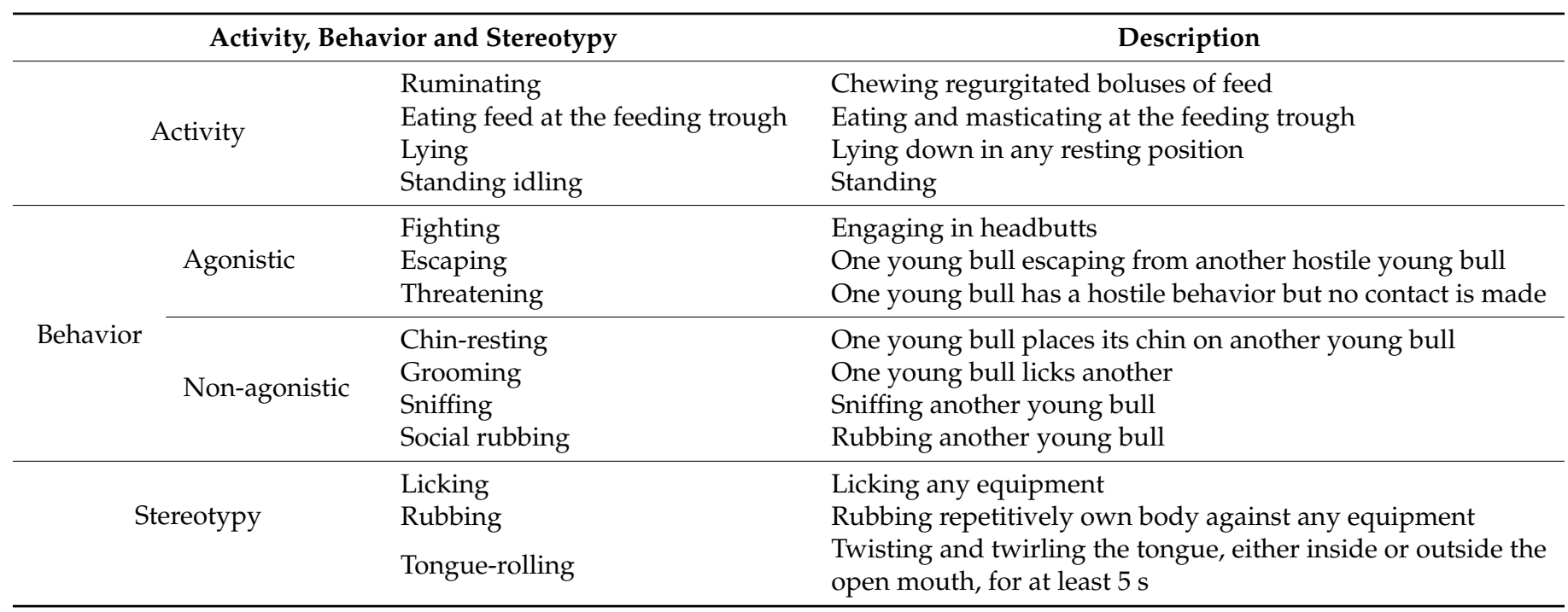

\subsection{Zootechnical Performances}

The duration of the fattening period was recorded for each young bull. Each young bull was weighed at the end of the fattening period. An individual average daily gain (ADG) $(\mathrm{kg} / \mathrm{d}$ ) for the entire fattening period was calculated as the change in body weight measured at the sorting facility and at the end of the fattening period divided by the number of days elapsed.

\subsection{Immune Gene Expression Analysis Using Reverse-Transcription Quantitative Polymerase Chain Reaction}

Total RNA was extracted from the blood of 15 (control) and 18 (pheromone) bulls randomly selected from each group on D0, after pheromone administration, and D8 using PAXgene Blood RNA Kit (Qiagen Courtaboeuf, France) as described by the manufacturer. RNA concentration was determined by measuring OD at $260 \mathrm{~nm}$ (OD260) and the RNA quality was assessed by calculating OD260/OD280 ratio NanoDrop spectrophotometer (NanoDrop Technologies, Wilmington, DE, USA). cDNA was generated with iScript Reverse Transcription Supermix for reverse-transcription quantitative polymerase chain reaction (RT-qPCR) (Bio-Rad, Hercules, CA, USA) from $400 \mathrm{ng}$ of RNA free of genomic DNA per reaction. Diluted cDNA (2-fold) was combined with primer/probe sets and IQ SYBR Green Supermix (Bio-Rad) according to the manufacturer's recommendations. The qPCR conditions, for the various genes tested in the study, were $95{ }^{\circ} \mathrm{C}$ for $30 \mathrm{~s}$, followed by 40 cycles with denaturation at $95^{\circ} \mathrm{C}$ for $5 \mathrm{~s}$ and annealing/elongation for $30 \mathrm{~s}$ at selected temperature-depending on the gene assessed. The efficiencies of all the qPCR assays were between $90 \%$ and $100 \%$, and we carefully followed MIQE guidelines recommendations [27]. The sequences of the primers used in the study were published previously (see Table 3) [28-33]. Real-time assays were run on a Bio-Rad CFX96 (Bio-Rad). The specificity of the qPCR reactions was assessed by analyzing the melting curves of the products and 
verifying the amplicon sizes. Samples were normalized internally by simultaneously using the average Cycle quantification $(C q)$ of two suitable reference genes (Beta actin (ACTB) and Glyceraldehyde-3-phosphate dehydrogenase (GAPDH)) in each sample to avoid any artifacts of variation in the target gene [28]. Then, qPCR data were expressed as relative values after Genex macro analysis (Bio-Rad) [34] using the Cq from the samples for the different transcripts.

Table 3. Primer abbreviations, full names, sequences, amplicon sizes (bp), annealing temperatures $\left({ }^{\circ} \mathrm{C}\right)$, and accession number or reference.

\begin{tabular}{|c|c|c|c|c|c|}
\hline \multicolumn{2}{|c|}{ Primer Abbreviation and Full Names } & $\begin{array}{c}\text { Primer Sequences: Sense (S) and } \\
\text { Anti-Sense (AS) }\end{array}$ & $\begin{array}{l}\text { Amplicon } \\
\text { Sizes (bp) }\end{array}$ & $\begin{array}{c}\text { Annealing } \\
\text { Temperatures } \\
\left({ }^{\circ} \mathrm{C}\right)\end{array}$ & $\begin{array}{l}\text { Accession } \\
\text { Number or } \\
\text { References }\end{array}$ \\
\hline REFERENCE & $\begin{array}{l}\text { ACTB } \\
\text { Beta actin }\end{array}$ & $\begin{array}{l}\text { S: ACGGGCAGGTCATCACCATC } \\
\text { AS: AGCACCGTGTTGGCGTAGAG }\end{array}$ & 166 & 67 & 28 \\
\hline GENES & $\begin{array}{l}\text { GADPH } \\
\text { Glyceraldehyde-3-phosphate dehydrogenase }\end{array}$ & $\begin{array}{l}\text { S: GGCATCGTGGAGGGACTTATG } \\
\text { AS: GCCAGTGAGCTTCCCGTTGAG }\end{array}$ & 186 & 62 & 28 \\
\hline \multirow{12}{*}{ CYTOKINES } & $\begin{array}{c}\text { IL12p40 } \\
\text { Interleukin } 12 \text { subunit p40 }\end{array}$ & $\begin{array}{l}\text { S: CACCAGCAGCTTCTTCATCA } \\
\text { AS: TACTCCCAGCTGACCTCCAC }\end{array}$ & 105 & 60 & 33 \\
\hline & IL4 & S: GCCACACGTGCTTGAACAAA & 63 & 60 & 30 \\
\hline & IL6 & S: TAAGCGCATGGTCGACAAAA & & & \\
\hline & Interleukin 6 & AS: TTGAACCCAGATTGGAAGCAT & 150 & 60 & 32 \\
\hline & IL8 (CXCL8) & S: AGAACTTCGATGCCAATGCAT & & & \\
\hline & Interleukin 8 & AS: GGGTTTAGGCAGACCTCGTTT & 150 & 60 & NM_173925 \\
\hline & IL17A & S: TCGTTAACCGGAGCACAAACT & & & \\
\hline & Interleukin 17A & AS: TGGCCTCCCAGATCACAGA & 120 & 60 & 32 \\
\hline & IL10 & S: AGAACCACGGGCCTGACA & 121 & 60 & 32 \\
\hline & Interleukin 10 & AS: ACCGCCTTGCTCTTGTTTTC & 121 & 00 & \\
\hline & $\begin{array}{c}\text { TGFß } \\
\text { Transforming growth factor } \beta\end{array}$ & $\begin{array}{l}\text { S: TGCTTCAGCTCCACAGAAAAGA } \\
\text { AS: AGGCAGAAATTGGCGTGGT }\end{array}$ & 116 & 60 & 32 \\
\hline & $\begin{array}{l}\text { IFNr } \\
\text { Interferon } \mathrm{r}\end{array}$ & $\begin{array}{l}\text { S: TTGAATGGCAGCTCTGAGAAAC } \\
\text { AS: TCTCTTCCGCTTTCTGAGGTTAGA }\end{array}$ & 150 & 60 & 32 \\
\hline \multirow{3}{*}{ CHEMOKINES } & CXCL6 & S: GAGAGCTGCGTTGTGTGTGT & & 60 & 29 \\
\hline & Chemokine (C-X-C motif) ligand 6 & AS: ACTTCCACCTTGGAGCACTG & 107 & 60 & 29 \\
\hline & $\begin{array}{c}\text { CCL20 } \\
\text { Chemokine (C-C motif) ligand } 20\end{array}$ & $\begin{array}{l}\text { S: TTCGACTGCTGTCTCCGATA } \\
\text { AS: GCACAACTTGTTTCACCCACT }\end{array}$ & 172 & 62 & 28 \\
\hline \multirow{5}{*}{$\begin{array}{l}\text { TRANSCRIPTION } \\
\text { FACTORS }\end{array}$} & $\begin{array}{c}\text { FOXP3 } \\
\text { Forkhead box P3 }\end{array}$ & $\begin{array}{l}\text { S: TGGTGCAATCTCTGGAGCAA } \\
\text { AS: GTCAGATGATGCCGCAGATG }\end{array}$ & 116 & 60 & 30 \\
\hline & GATA-3 & S: CCAGACCAGAAACCGAAAAA & 234 & 62 & 31 \\
\hline & $\begin{array}{l}\text { Trans-acting T-cell-specific transcription } \\
\text { factor GATA-3 }\end{array}$ & AS: ACCATACTGGAAGGGTGGTG & 234 & 62 & 31 \\
\hline & $\begin{array}{l}\text { RORr(RORC gene) } \\
\text { RAR-related orphan receptor gamma }\end{array}$ & $\begin{array}{l}\text { S: ACAGCCCTCGTCCTCATCAATGCC } \\
\text { AS: TGGGTGGCAGCTTTGCCAGGATA }\end{array}$ & 145 & 60 & 30 \\
\hline & TBX21 & $\begin{array}{l}\text { S: CGAGGACTATATACTGCCGC } \\
\text { AS: CAAGACCACGTCCACATACA }\end{array}$ & 133 & 61 & 31 \\
\hline
\end{tabular}

\subsection{Statistical Analysis}

Most calculations and statistical analyses were performed in the open-source environment $\mathrm{R}$ version 3.5.1. (R Development Core Team, Vienna, Austria). The characteristics of young bulls assigned to the two treatment groups were compared to assess homogeneity: Student's $t$-test was used for continuous variables after checking normality using Shapiro-Wilk test. Then, a mixed effects logistic regression model using the glm function from the package lmertest was used to characterize the association between the exposure to pheromone and BRD diagnosis (diseased or healthy). The individual bull was the experimental unit. Fattening operation and pen were considered as random factors. An interaction between the date of clinical examination and BRD diagnosis was included in the statistical model.

Proportions and count were used to describe activity and behavioral observations. Because they displayed a skewed distribution, permutation tests with 1000 replications were used to calculate $p$-values. Hypothesis $\mathrm{H} 0$ is that an activity or behavioral observation has a significant effect. A mixed linear model was used with the initial dataset to test this effect, and the Chi-square statistic was calculated for each activity or behavioral observation. Then, 1000 replications were performed with a random permutation of group (pheromone or control) for young bulls at each replication while keeping the same proportion of pheromone groups and control groups, a random permutation of date of 
clinical examination (D0, D8, or D30), and a random permutation of number of young bulls per pen while keeping the same number of young bulls receiving pheromone as in the initial dataset. For each activity or behavioral observation, 1000 values of Chi-square statistic were then obtained. The $95 \%$ percentile of repartition of these 1000 values was calculated and compared with the value obtained with the initial dataset: if superior, then $\mathrm{HO}$ is rejected, thus the activity and behavioral observation has a significant effect.

A mixed linear regression model using the lme function from the nlme package was used to characterize the association between the exposure to pheromone and ADG for the entire fattening period. The individual bull was the experimental unit. A "pen within fattening operation" nested random effect was added to the model.

Then, relative expressions of transcripts were compared using Wilcoxon signed rank test since data were paired and non-normally distributed. All comparisons were carried out using GraphPad Prism (GraphPad Software version 7.0, San Diego, CA, USA). p-values less than 0.05 were considered statistically significant.

\section{Results}

Regarding animals included in the study, no significant difference was present between the two treatment groups regarding weight at entry $(\mathrm{T}=-0.33, \mathrm{df}=263 ; p=0.7393)$. However, young bulls from the pheromone group were older than young bulls in the control group $(\mathrm{T}=-2.1647, \mathrm{df}=263, p=0.031)$ (see Table 1). No significant difference was observed between the two treatment groups regarding number of cow-calf farms of origin per batch $(\mathrm{T}=0.29214, \mathrm{df}=21, p=0.773)$.

\subsection{Clinical Signs}

Clinical data were obtained for 237 young bulls (137 in the pheromone group and 100 in the control group) on D8 and 230 young bulls (139 in the pheromone group and 91 in the control group) on D30. On D8, 15\% (36/237) of the young bulls were affected by BRD. The diagnosis was established when the animal displayed: (i) nasal or ocular discharge or cough; and (ii) increase in respiratory rate or depression. The morbidity rate was $19 \%(26 / 137)$ in the pheromone group and $1 \%(10 / 100)$ in the control group. On D30, $8 \%(19 / 230)$ of the young bulls were sick with a morbidity rate of $4 \%(6 / 139)$ in the pheromone group and 14\% (13/91) in the control group.

The results of the logistic regression model (Table 4 ) show that the interaction between exposure to pheromone and day of clinical exam was significantly $(p=0.001)$ associated with disease, showing that more clinical cases $(\mathrm{OR}=8.20)$ were observed in the control group compared to the pheromone group on D30, while more clinical signs were observed in the pheromone group than in the control group on D8.

Table 4. Association between the exposure to pheromone and BRD diagnosis (diseased or healthy). The data were collected from 265 young bulls.

\begin{tabular}{|c|c|c|c|c|c|}
\hline \multirow{3}{*}{\multicolumn{2}{|c|}{ Variables and Levels }} & \multicolumn{3}{|c|}{ Odds Ratio } & \multirow{3}{*}{$p$-Value } \\
\hline & & \multirow{2}{*}{ Estimate } & \multicolumn{2}{|c|}{ 95\% Confidence Interval } & \\
\hline & & & Lower Bound & Upper BOUND & \\
\hline \multirow{2}{*}{ Exposure to pheromone } & Control & Reference & & & \\
\hline & Pheromone & 0.48 & -0.20 & 1.10 & 0.84 \\
\hline \multirow{2}{*}{ Day of clinical examination } & D8 & Reference & & & \\
\hline & D30 & 0.19 & -0.07 & 0.45 & 0.08 \\
\hline \multicolumn{2}{|c|}{ Pheromone $\times$ Day of clinical examination } & 8.20 & 2.32 & 31.90 & 0.001 \\
\hline
\end{tabular}

\subsection{Activities and Behaviors}

Activities and behaviors were observed for the 265 young bulls on D0, D8, and D30. The proportion of animals standing was significantly higher on D8 and D30 than on D0 
$(p<0.001)$ for all pens. The statistical model did not show any effect of the treatment group on the proportion of animals standing idling, eating food at the feeding trough, or ruminating. Over the entire period of observation, animals from the pheromone group moved significantly more than animals from the control group $(p<0.05)$.

No effect of day of observation (D0, D8, or D30) or treatment on the number of agonistic interactions was demonstrated by the statistical model used. Analysis of the results shows that the number of agonistic interactions increases depending on the number of animals in a batch, regardless of the batch considered $(p<0.05)$ (Figure 1$)$. Too few non-agonistic interactions and stereotypies were observed to allow meaningful statistical analysis.

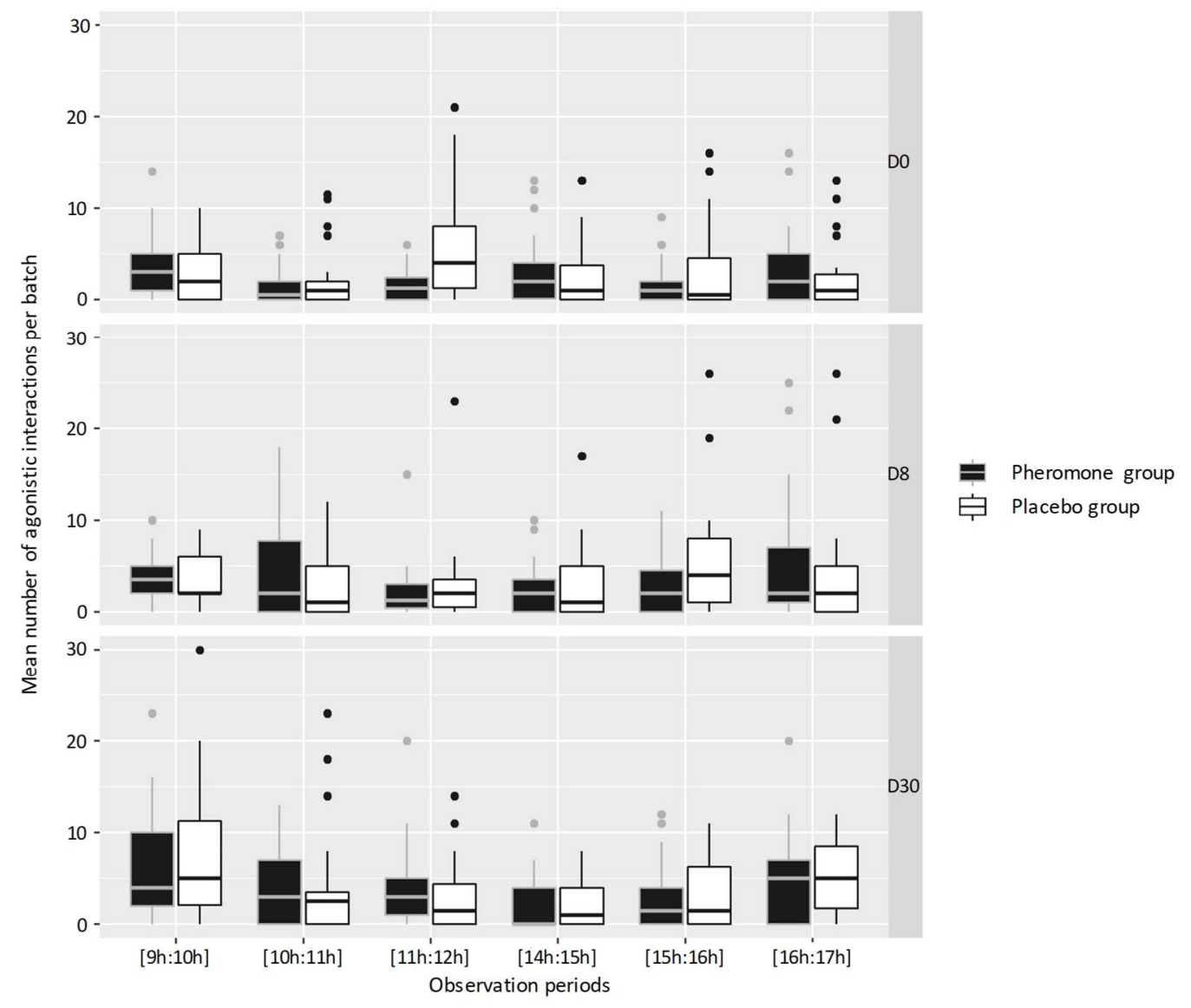

Figure 1. Activity and behavioral observations.

\subsection{Average Daily Gain}

The ADG for the entire fattening period was observed for 164 young bulls. The results of the mixed linear regression model show that exposure to pheromone was not significantly associated with ADG (Table 5).

Table 5. Associations among exposure to pheromone, pen-size, and average daily gain $(\mathrm{kg} / \mathrm{d})$ of young bulls for the entire fattening period. The data were collected from 164 young bulls.

\begin{tabular}{|c|c|c|c|c|c|}
\hline \multirow{3}{*}{ Variables and Levels } & & \multicolumn{3}{|c|}{ Mean ADG $^{1}$} & \multirow{3}{*}{$p$-Value } \\
\hline & & \multirow{2}{*}{ Estimate } & \multicolumn{2}{|c|}{ 95\% Confidence Interval } & \\
\hline & & & Lower Bound & Upper Bound & \\
\hline Intercept & & 1.498 & & & \\
\hline \multirow{2}{*}{ Exposure to pheromone } & Control & 1.48 & 1.33 & 1.67 & 0.98 \\
\hline & Pheromone & 1.48 & 1.33 & 1.67 & \\
\hline
\end{tabular}

\footnotetext{
${ }^{1}$ ADG (average daily gain) $(\mathrm{kg} / \mathrm{d})$ was calculated for the entire fattening period.
} 


\subsection{Assessment of Immune Transcript Expression by Quantitative Polymerase Chain Reaction}

To assess the impact of the pheromone treatment on the expression of various immune transcripts, we collected blood from the young bulls, extracted RNA from the cells, and measured the expression of different transcripts. The selected transcripts were associated with the different common lymphocyte Thelper responses (Th1, Th2, Th17, and T regulator) as well as with inflammation for the last ones (see Table 3). On D0 and D8, we did not observe significant differences $(p>0.05)$ for the vast majority of the assessed transcripts (Table 6). However, an increasing trend for IL12p40 transcripts in the blood of control group bulls in comparison to the blood of pheromone group bulls was identified $(p=0.073)$ (Figure 2 and Table 6). Similarly, an increasing trend for IL6 transcripts in control group was observed on D8 ( $p=0.055)$ (Figure 2 and Table 6). Interestingly, for IL8, significant differences were identified on D8 with more IL8 transcripts in the pheromone group compared to control group (see Figure 1 and Table 6). On D0, the trend was similar, but the difference was not significant ( $p=0.053)$.

Table 6. Statistical comparisons between mRNA relative expressions in control and pheromone groups on Day 0 (D0) and D8. Levels of expression in controls are shown in the second column (high, amplification around 17-26 cycle quantification (Cq); moderate, 26-31 Cq; low, $>31 C q$ ). $p$-values are presented in other columns. As the data were not paired and non-normally distributed, group means were compared using the Wilcoxon signed rank test (exact). ${ }^{* *} p<0.010$. In bold, significant $p$-values and $p$-values nearly significant; ns, not significant; SEM, standard error of the mean.

\begin{tabular}{|c|c|c|c|c|c|c|c|}
\hline \multirow{3}{*}{$\begin{array}{l}\text { Messenger } \\
\text { RNAs }\end{array}$} & \multirow{3}{*}{$\begin{array}{l}\text { Levels of } \\
\text { Expression } \\
\text { (Controls) }\end{array}$} & \multicolumn{3}{|c|}{ D0 } & \multicolumn{3}{|c|}{ D8 } \\
\hline & & \multicolumn{2}{|c|}{$\begin{array}{c}\text { mRNA Relative } \\
\text { Expressions } \pm \text { SEM }\end{array}$} & \multirow{2}{*}{$\begin{array}{l}\text { Pheromone } \\
\text { vs. Control }\end{array}$} & \multicolumn{2}{|c|}{$\begin{array}{c}\text { mRNA Relative } \\
\text { Expressions } \pm \text { SEM }\end{array}$} & \multirow{2}{*}{$\begin{array}{l}\text { Pheromone } \\
\text { vs. Control }\end{array}$} \\
\hline & & $\begin{array}{l}\text { Control } \\
(N=15)\end{array}$ & $\begin{array}{c}\text { Pheromone } \\
(N=18)\end{array}$ & & $\begin{array}{l}\text { Control } \\
(N=15)\end{array}$ & $\begin{array}{l}\text { Pheromone } \\
\quad(N=18)\end{array}$ & \\
\hline CCL20 & low & $13.87 \pm 4.13$ & $20.72 \pm 4.84$ & ns & $12.38 \pm 1.79$ & $18.24 \pm 3.26$ & ns \\
\hline CXCL6 & moderate & $5.56 \pm 1.64$ & $14.77 \pm 6.74$ & ns & $5.91 \pm 1.32$ & $8.84 \pm 2.18$ & ns \\
\hline FOXP3 & moderate & $6.3 \pm 0.9$ & $5.85 \pm 0.77$ & ns & $4.86 \pm 0.71$ & $4.39 \pm 0.71$ & ns \\
\hline GATA-3 & high & $6.32 \pm 0.92$ & $8.15 \pm 1.26$ & ns & $4.72 \pm 0.51$ & $4.7 \pm 0.62$ & ns \\
\hline $\mathrm{IFNr}$ & low & $18.44 \pm 4.49$ & $45.86 \pm 16.27$ & ns & $17.93 \pm 3.92$ & $37.83 \pm 11.35$ & ns \\
\hline IL10 & moderate & $4.15 \pm 0.70$ & $4.57 \pm 1.11$ & ns & $2.68 \pm 0.51$ & $2.76 \pm 0.25$ & ns \\
\hline IL12 p40 & moderate & $213.23 \pm 40.59$ & $155.05 \pm 47.51$ & 0.073 & $87.49 \pm 22.68$ & $82.28 \pm 15.69$ & ns \\
\hline IL17A & low & $22.06 \pm 10.57$ & $34.94 \pm 15.77$ & $\mathrm{~ns}$ & $57.53 \pm 30.78$ & $43.67 \pm 14.51$ & $\mathrm{~ns}$ \\
\hline IL4 & low & $6.28 \pm 4.00$ & $0.81 \pm 0.45$ & ns & $1.13 \pm 0.71$ & $3.34 \pm 2.13$ & ns \\
\hline IL6 & low & $11.32 \pm 4.68$ & $11.15 \pm 3.88$ & ns & $11.33 \pm 2.21$ & $5.55 \pm 1.78$ & 0.055 \\
\hline IL8 & moderate & $231.45 \pm 82.35$ & $321.85 \pm 62.56$ & 0.053 & $178.25 \pm 95.58$ & $330.61 \pm 104.61$ & $0.004 * *$ \\
\hline RORy & moderate & $6.25 \pm 0.86$ & $5.32 \pm 0.46$ & ns & $4.86 \pm 0.64$ & $5.03 \pm 0.64$ & ns \\
\hline TBX21 & moderate & $8.51 \pm 1.47$ & $9.33 \pm 1.66$ & ns & $4.78 \pm 0.74$ & $3.8 \pm 0.60$ & ns \\
\hline TGFß & high & $3.36 \pm 0.38$ & $3.12 \pm 0.32$ & ns & $2.78 \pm 0.37$ & $3.32 \pm 0.18$ & $\mathrm{~ns}$ \\
\hline
\end{tabular}
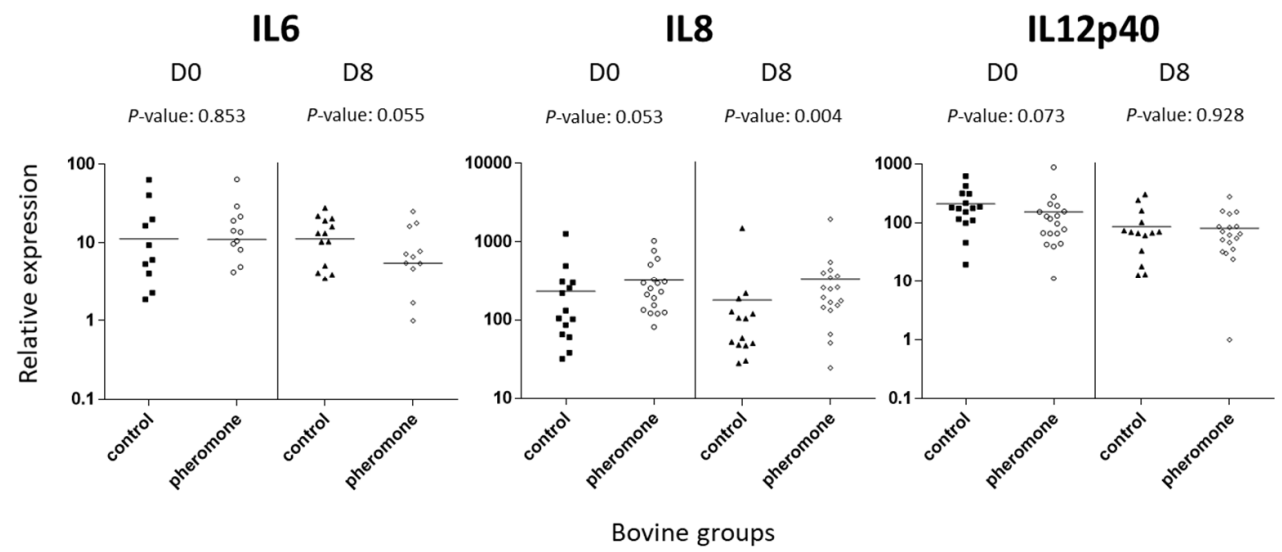

Figure 2. Blood IL6, IL8, and IL12p40 transcripts are differentially expressed between treated and untreated young bulls. 


\section{Discussion}

The fattening period in beef cattle is one of the most challenging phases within the production cycle. Indeed, young animals are exposed to multiple stresses of different natures with major consequences in terms of welfare, health, and productivity. Stress, especially when consecutive to weaning and transportation, has a major role in the onset of various respiratory infections during fattening through its deleterious effects on the immune defenses [2,5,35]. Bacterial respiratory infection is one of the main causes of antimicrobial molecule use during the metaphylaxis procedure and curative treatments $[2,7,8]$. The development and spreading of antimicrobial resistance makes the identification and establishment of alternative approaches to antimicrobial molecules to reduce their use necessary. Among the potential alternatives, bovine appeasing pheromone is an attractive one. As stated above, several previous reports have shown a benefit when appeasing pheromones were used in dairy and beef cattle production [22,24-26]. In our study, carried out in fattening units from western France using Charolais young bulls, we observed that significantly more clinical cases were detected on day 30 (D30) in the control group than in the group of bulls which received appeasing pheromone, while the opposite was observed earlier on D8. This observation is both similar and different from what was previously reported by Colombo and collaborators [26]. Indeed, in their study, incidence of BRD was greater $(p<0.05)$ in Angus steers that received appeasing pheromone than in the control group during Days 6-10 and 19-23, although overall BRD incidence did not differ between treatments. Moreover, a higher proportion $(p=0.04)$ of the appeasing pheromone group diagnosed with BRD required one antimicrobial treatment to retrieve health compared to control group [26]. Similarly, in our study, we detected more clinical signs in the pheromone group than in the control group early, on D8. Conversely, on D30, there were fewer BRD-associated clinical signs in the pheromone group than in the control group. Several differences between studies could be identified. For instance, the timing of pheromone administration and the measured parameters were different. In our study, we determined the presence or absence of BRD without any monitoring of pathogens, while Colombo and collaborators monitored the cumulative incidence of BRD clinical signs during a 45-day feedlot-receiving period of beef steers administered an appeasing pheromone at feedlot entry and measured the serum concentration of antibodies against various pathogens [26]. Regarding activities and behavior, we did not observe any differences between groups. Similarly, the mixed linear regression model showed that exposure to pheromone was not significantly associated with final ADG. In other studies $[25,26]$, the authors identified positive impacts of appeasing pheromone over body weight gain; however, the benefit was not sustained throughout the 45-day experiment in Bos indicus-influenced beef cattle [25]. Moreover, in these studies, the authors measured intermediate ADG, while we assessed final ADG.

In the last part of our study, we assessed the whole blood expression of various transcripts associated with the immune response. The analysis of blood has been demonstrated to be a valuable approach to assess various health aspects in bovine [36,37]. In our study, we selected a limited number of target genes encompassing Th1, Th2, Th17, and Treg cytokines, as well as the associated transcription factors and chemokines. Most of the time, no significant differences were observed between control and pheromone groups of bulls on both Day 0 and Day 8 (after pheromone administration). However, for IL8 transcripts, we observed a clear difference between the pheromone group and control group on Day 8 with a higher expression of IL8 transcripts in the pheromone group than in the control group. Meanwhile, more respiratory clinical signs were identified in the pheromone group than in the control group. IL8 or CXCL8 is a well-known cytokine which was first purified and molecularly cloned as a neutrophil chemotactic factor from lipopolysaccharide-stimulated human mononuclear cell supernatants [38-40]. Bovine IL8 has similar roles to its human counterpart and can massively attract neutrophils to the sites of inflammation consecutive to tissue alterations induced by respiratory pathogens [41-43]. A positive effect of increased IL8 transcripts might be suggested in our conditions, especially since we observed fewer 
clinical cases of BRD in the pheromone group than in the control group on Day 30. A higher amount of IL8 in the pheromone group than in the control group could have attracted more neutrophils to the sites of inflammation and thus could have promoted a quicker resolution of respiratory infections in the pheromone group. This hypothesis is supported by observations from multiple reports, where IL8 protective effects against respiratory infections-particularly bacterial infections as it is less clear for viral infections-were identified [40,44,45]. Moreover, administration of recombinant bovine IL8 was shown to also have positive effects on uterine health and milk production [46]. Thus, monitoring of blood IL8 transcripts in young bulls could potentially bring information regarding the onset of clinical respiratory signs associated with infectious diseases. Was the increased expression of IL8 transcripts altered by pheromone treatment or was it just a direct and simple consequence of tissue damages caused by respiratory pathogens infecting bulls during the fattening period? That question cannot be answered here. However, IL8 definitely participates in the resolution of bacterial respiratory infections and superinfections through its action on neutrophils. Furthermore, it would be important to assess the IL8 protein concentration and respiratory infections over time in bovine treated with appeasing pheromones. Indeed, we cannot totally exclude discrepancies between transcript and protein expressions. Additionally, there was a clear trend for a lower expression of the IL6 transcripts in the pheromone group than in the control group. This could account for a low inflammatory status in pheromone group but further research is required to confirm this hypothesis. It would have been interesting to follow the concentrations of glucocorticosteroids and acute phase proteins such as fibrinogen in the blood compartment, as was carried out in some reports $[25,26,46]$. Moreover, some measures of IL8 transcript expression and protein production in the control and pheromone groups on D30 would be informative. We did not do this in the current study, which would be a valuable addition to a future experiment as an attempt to link immune transcript expressions to stress and inflammatory global status.

In our study, appeasing pheromones showed, after 30 days, a slight beneficial impact on bovine health, which is in line with previous studies [22,24-26] also reporting an interest in using these molecules in cattle to improve animal health.

\section{Conclusions}

In the current study, we showed that appeasing pheromone may have an impact on the bovine respiratory disease complex in the context of the fattening period. Our results confirm the potential of appeasing pheromones as a complementary approach in the management of young bulls in fattening units. However, further studies are warranted to determine the extent of the beneficial effects of appeasing pheromones observed on Day 30 and precisely decipher the mechanisms underlying these effects.

Author Contributions: Conceived and designed the experiments, S.A., B.M., M.G., L.M., A.A., and L.B.-L.; methodology, C.H. and J.B.; software, C.H., F.M., B.M., M.G., L.M., and L.B.-L.; validation, S.A., F.R., F.M., B.M., M.G., L.M., and L.B.-L.; formal analysis, C.H., S.A., F.R., F.M., B.M., M.G., A.A., L.M., J.Z., and L.B.-L.; investigation, C.H. and J.B.; resources, S.A. and F.M.; writing-original draft preparation, S.A. and F.M.; writing-review and editing, S.A., F.R., J.Z., and F.M.; supervision, S.A. and F.M.; project administration, S.A. and F.M.; and funding acquisition, S.A. and F.M. All authors have read and agreed to the published version of the manuscript.

Funding: This research was supported by the research program "For and on Regional Development" PSDR 4 Grand Ouest funded by INRAE and the Régions Bretagne, Normandie, Nouvelle Aquitaine and Pays de Loire as part of the SANT'Innov project and the Plan ÉcoAntibio du Ministère de l'Agriculture et de l'Alimentation (France).

Institutional Review Board Statement: The farm bulls were housed and maintained in compliance with the French Ministry of Agriculture and Fishing standards for the protection of animals. The protocol was approved locally (2021_001). 
Data Availability Statement: No new data were created or analyzed in this study. Data sharing is not applicable to this article.

Acknowledgments: We offer our great appreciation to Lucie Hallet for technical assistance during her internship in our lab and Maxime Legris for his help regarding the statistical analysis.

Conflicts of Interest: The authors declare no conflict of interest.

\section{References}

1. Assié, S.; Seegers, H.; Makoschey, B.; Désiré-Bousquié, L.; Bareille, N. Exposure to Pathogens and Incidence of Respiratory Disease in Young Bulls on Their Arrival at Fattening Operations in France. Vet. Rec. 2009, 165, 195-199. [CrossRef]

2. Bell, R.L.; Turkington, H.L.; Cosby, S.L. The Bacterial and Viral Agents of BRDC: Immune Evasion and Vaccine Developments. Vaccines 2021, 9, 337. [CrossRef] [PubMed]

3. Ellis, J.A. The Immunology of the Bovine Respiratory Disease Complex. Vet. Clin. N. Am. Food Anim. Pract. 2001, 17, 535-550. [CrossRef]

4. $\quad$ Ellis, J.A. Update on Viral Pathogenesis in BRD. Anim. Health Res. Rev. 2009, 10, 149-153. [CrossRef]

5. Cooke, R.F. Invited Paper: Nutritional and Management Considerations for Beef Cattle Experiencing Stress-Induced Inflammation. This article was based on a presentation at the ARPAS Symposium “Understanding Inflammation and Inflammatory Biomarkers to Improve Animal Performance" at the 2016 Joint Annual Meeting, July 19-23, 2016, Salt Lake City, Utah. Prof. Anim. Sci. 2017, 33, 1-11. [CrossRef]

6. McMullen, C.; Orsel, K.; Alexander, T.W.; van der Meer, F.; Plastow, G.; Timsit, E. Comparison of the Nasopharyngeal Bacterial Microbiota of Beef Calves Raised without the Use of Antimicrobials between Healthy Calves and Those Diagnosed with Bovine Respiratory Disease. Vet. Microbiol. 2019, 231, 56-62. [CrossRef]

7. Watts, J.L.; Sweeney, M.T. Antimicrobial Resistance in Bovine Respiratory Disease Pathogens: Measures, Trends, and Impact on Efficacy. Vet. Clin. N. Am. Food Anim. Pract. 2010, 26, 79-88. [CrossRef] [PubMed]

8. Stanford, K.; Zaheer, R.; Klima, C.; McAllister, T.; Peters, D.; Niu, Y.D.; Ralston, B. Antimicrobial Resistance in Members of the Bacterial Bovine Respiratory Disease Complex Isolated from Lung Tissue of Cattle Mortalities Managed with or without the Use of Antimicrobials. Microorganisms 2020, 8, 288. [CrossRef]

9. Carroll, J.A.; Forsberg, N.E. Influence of Stress and Nutrition on Cattle Immunity. Vet. Clin. N. Am. Food Anim. Pract. 2007, 23, 105-149. [CrossRef]

10. Mounier, L.; Veissier, I.; Boissy, A. Behavior, Physiology, and Performance of Bulls Mixed at the Onset of Finishing to Form Uniform Body Weight Groups. J. Anim. Sci. 2005, 83, 1696-1704. [CrossRef]

11. Aich, P.; Jalal, S.; Czuba, C.; Schatte, G.; Herzog, K.; Olson, D.J.H.; Ross, A.R.S.; Potter, A.A.; Babiuk, L.A.; Griebel, P. Comparative Approaches to the Investigation of Responses to Stress and Viral Infection in Cattle. OMICS 2007, 11, 413-434. [CrossRef]

12. Hermann, G.; Tovar, C.A.; Beck, F.M.; Allen, C.; Sheridan, J.F. Restraint Stress Differentially Affects the Pathogenesis of an Experimental Influenza Viral Infection in Three Inbred Strains of Mice. J. Neuroimmunol. 1993, 47, 83-94. [CrossRef]

13. Chirase, N.K.; Greene, L.W.; Purdy, C.W.; Loan, R.W.; Auvermann, B.W.; Parker, D.B.; Walborg, E.F.; Stevenson, D.E.; Xu, Y.; Klaunig, J.E. Effect of Transport Stress on Respiratory Disease, Serum Antioxidant Status, and Serum Concentrations of Lipid Peroxidation Biomarkers in Beef Cattle. Am. J. Vet. Res. 2004, 65, 860-864. [CrossRef]

14. Mormede, P.; Soissons, J.; Bluthe, R.M.; Raoult, J.; Legarff, G.; Levieux, D.; Dantzer, R. Effect of Transportation on Blood Serum Composition, Disease Incidence, and Production Traits in Young Calves. Influence of the Journey Duration. Ann. Rech. Vet. 1982, 13, 369-384. [PubMed]

15. Hickey, M.C.; Drennan, M.; Earley, B. The Effect of Abrupt Weaning of Suckler Calves on the Plasma Concentrations of Cortisol, Catecholamines, Leukocytes, Acute-Phase Proteins and in Vitro Interferon-Gamma Production. J. Anim. Sci. 2003, 81, $2847-2855$. [CrossRef]

16. Blecha, F.; Boyles, S.L.; Riley, J.G. Shipping Suppresses Lymphocyte Blastogenic Responses in Angus and Brahman X Angus Feeder Calves. J. Anim. Sci. 1984, 59, 576-583. [CrossRef]

17. Sporer, K.R.B.; Xiao, L.; Tempelman, R.J.; Burton, J.L.; Earley, B.; Crowe, M.A. Transportation Stress Alters the Circulating Steroid Environment and Neutrophil Gene Expression in Beef Bulls. Vet. Immunol. Immunopathol. 2008, 121, 300-320. [CrossRef] [PubMed]

18. Masset, N.; Meurens, F.; Marie, M.; Lesage, P.; Lehébel, A.; Brisseau, N.; Assié, S. Effectiveness of Two Intranasal Vaccines for the Control of Bovine Respiratory Disease in Newborn Beef Calves: A Randomized Non-Inferiority Multicentre Field Trial. Vet. J. 2020, 263, 105532. [CrossRef]

19. Temple, D.; Barthélémy, H.; Mainau, E.; Cozzi, A.; Amat, M.; Canozzi, M.E.; Pageat, P.; Manteca, X. Preliminary Findings on the Effect of the Pig Appeasing Pheromone in a Slow Releasing Block on the Welfare of Pigs at Weaning. Porcine Health Manag. 2016, 2, 13. [CrossRef]

20. Taylor, K.; Mills, D.S. A Placebo-Controlled Study to Investigate the Effect of Dog Appeasing Pheromone and Other Environmental and Management Factors on the Reports of Disturbance and House Soiling during the Night in Recently Adopted Puppies (Canis familiaris). Appl. Anim. Behav. Sci. 2007, 105, 358-368. [CrossRef] 
21. Falewee, C.; Gaultier, E.; Lafont, C.; Bougrat, L.; Pageat, P. Effect of a Synthetic Equine Maternal Pheromone during a Controlled Fear-Eliciting Situation. Appl. Anim. Behav. Sci. 2006, 101, 144-153. [CrossRef]

22. Osella, M.C.; Cozzi, A.; Spegis, C.; Turille, G.; Barmaz, A.; Lecuelle, C.L.; Teruel, E.; Bienboire-Frosini, C.; Chabaud, C.; Bougrat, L.; et al. The Effects of a Synthetic Analogue of the Bovine Appeasing Pheromone on Milk Yield and Composition in Valdostana Dairy Cows during the Move from Winter Housing to Confined Lowland Pastures. J. Dairy Res. 2018, 85, 174-177. [CrossRef]

23. Pageat, P. Appeasing Pheromones to Decrease Stress, Anxiety and Aggressiveness 1998. European Patent EP 0948,963 A1; U.S. Patent 6,054,481; U.S. Patent 6,077,867; U.S. Patent 6,169,113 B1; Japan Patent 2000-528279; Japan Patent 980,298, 21 January 1998.

24. Angeli, B.; Cappellozza, B.; Moraes Vasconcelos, J.L.; Cooke, R.F. Administering an Appeasing Substance to Gir $\times$ Holstein Female Dairy Calves on Pre-Weaning Performance and Disease Incidence. Animals 2020, 10, 1961. [CrossRef]

25. Cooke, R.F.; Millican, A.; Brandão, A.P.; Schumaher, T.F.; de Sousa, O.A.; Castro, T.; Farias, R.S.; Cappellozza, B.I. Short Communication: Administering an Appeasing Substance to Bos Indicus-Influenced Beef Cattle at Weaning and Feedlot Entry. Animal 2020, 14, 566-569. [CrossRef] [PubMed]

26. Colombo, E.A.; Cooke, R.F.; Brandão, A.P.; Wiegand, J.B.; Schubach, K.M.; Duff, G.C.; Gouvêa, V.N.; Cappellozza, B.I. Administering an Appeasing Substance to Optimize Performance and Health Responses in Feedlot Receiving Cattle. J. Anim. Sci. 2020, 98, 1-8. [CrossRef]

27. Bustin, S.A.; Benes, V.; Garson, J.A.; Hellemans, J.; Huggett, J.; Kubista, M.; Mueller, R.; Nolan, T.; Pfaffl, M.W.; Shipley, G.L.; et al. The MIQE Guidelines: Minimum Information for Publication of Quantitative Real-Time PCR Experiments. Clin. Chem. 2009, 55, 611-622. [CrossRef] [PubMed]

28. Bougarn, S.; Cunha, P.; Gilbert, F.B.; Meurens, F.; Rainard, P. Technical Note: Validation of Candidate Reference Genes for Normalization of Quantitative PCR in Bovine Mammary Epithelial Cells Responding to Inflammatory Stimuli. J. Dairy Sci. 2011, 94, 2425-2430. [CrossRef]

29. Shukla, S.K.; Shukla, S.; Chauhan, A.; Sarvjeet, N.; Khan, R.; Ahuja, A.; Singh, L.V.; Sharma, N.; Prakash, C.; Singh, A.V.; et al. Differential Gene Expression in Mycobacterium bovis Challenged Monocyte-Derived Macrophages of Cattle. Microb. Pathog. 2017, 113, 480-489. [CrossRef]

30. Maeda, Y.; Ohtsuka, H.; Tomioka, M.; Oikawa, M. Effect of Progesterone on Th1/Th2/Th17 and Regulatory T Cell-Related Genes in Peripheral Blood Mononuclear Cells during Pregnancy in Cows. Vet. Res. Commun. 2013, 37, 43-49. [CrossRef]

31. Martin, E.T.; Kuypers, J.; Wald, A.; Englund, J.A. Multiple versus Single Virus Respiratory Infections: Viral Load and Clinical Disease Severity in Hospitalized Children: Viral Coinfection in Children. Influenza Other Respir. Viruses 2012, 6, 71-77. [CrossRef]

32. Whelehan, C.J.; Meade, K.G.; Eckersall, P.D.; Young, F.J.; O'Farrelly, C. Experimental Staphylococcus aureus Infection of the Mammary Gland Induces Region-Specific Changes in Innate Immune Gene Expression. Vet. Immunol. Immunopathol. 2011, 140, 181-189. [CrossRef] [PubMed]

33. Sheridan, M.P.; Browne, J.A.; Doyle, M.B.; Fitzsimons, T.; McGill, K.; Gormley, E. IL-10 Suppression of IFN- $\gamma$ Responses in Tuberculin-Stimulated Whole Blood from Mycobacterium bovis Infected Cattle. Vet. Immunol. Immunopathol. 2017, 189 , 36-42. [CrossRef] [PubMed]

34. Vandesompele, J.; De Preter, K.; Pattyn, F.; Poppe, B.; Van Roy, N.; De Paepe, A.; Speleman, F. Accurate Normalization of Real-Time Quantitative RT-PCR Data by Geometric Averaging of Multiple Internal Control Genes. Genome Biol. 2002, 3, RESEARCH0034. [CrossRef] [PubMed]

35. McGill, J.L.; Sacco, R.E. The Immunology of Bovine Respiratory Disease. Vet. Clin. N. Am. Food Anim. Pract. 2020, 36, 333-348. [CrossRef] [PubMed]

36. Maruyama, S.R.; Carvalho, B.; González-Porta, M.; Rung, J.; Brazma, A.; Gustavo Gardinassi, L.; Ferreira, B.R.; Banin, T.M.; Veríssimo, C.J.; Katiki, L.M.; et al. Blood Transcriptome Profile Induced by an Efficacious Vaccine Formulated with Salivary Antigens from Cattle Ticks. NPJ Vaccines 2019, 4, 1-10. [CrossRef]

37. Scott, M.A.; Woolums, A.R.; Swiderski, C.E.; Perkins, A.D.; Nanduri, B.; Smith, D.R.; Karisch, B.B.; Epperson, W.B.; Blanton, J.R. Whole Blood Transcriptomic Analysis of Beef Cattle at Arrival Identifies Potential Predictive Molecules and Mechanisms That Indicate Animals That Naturally Resist Bovine Respiratory Disease. PLoS ONE 2020, 15, 7507. [CrossRef]

38. Matsushima, K.; Morishita, K.; Yoshimura, T.; Lavu, S.; Kobayashi, Y.; Lew, W.; Appella, E.; Kung, H.F.; Leonard, E.J.; Oppenheim, J.J. Molecular Cloning of a Human Monocyte-Derived Neutrophil Chemotactic Factor (MDNCF) and the Induction of MDNCF MRNA by Interleukin 1 and Tumor Necrosis Factor. J. Exp. Med. 1988, 167, 1883-1893. [CrossRef]

39. Yoshimura, T.; Matsushima, K.; Tanaka, S.; Robinson, E.A.; Appella, E.; Oppenheim, J.J.; Leonard, E.J. Purification of a Human Monocyte-Derived Neutrophil Chemotactic Factor That Has Peptide Sequence Similarity to Other Host Defense Cytokines. Proc. Natl. Acad. Sci. USA 1987, 84, 9233-9237. [CrossRef]

40. Mukaida, N. Pathophysiological Roles of Interleukin-8/CXCL8 in Pulmonary Diseases. Am. J. Physiol. Lung Cell. Mol. Physiol. 2003, 284, L566-L577. [CrossRef]

41. Mitchell, G.B.; Albright, B.N.; Caswell, J.L. Effect of Interleukin-8 and Granulocyte Colony-Stimulating Factor on Priming and Activation of Bovine Neutrophils. Infect. Immun. 2003, 71, 1643-1649. [CrossRef]

42. Caswell, J.L.; Middleton, D.M.; Gordon, J.R. Production and Functional Characterization of Recombinant Bovine Interleukin-8 as a Specific Neutrophil Activator and Chemoattractant. Vet. Immunol. Immunopathol. 1999, 67, 327-340. [CrossRef] 
43. Caswell, J.L.; Middleton, D.M.; Sorden, S.D.; Gordon, J.R. Expression of the Neutrophil Chemoattractant Interleukin-8 in the Lesions of Bovine Pneumonic Pasteurellosis. Vet. Pathol. 1998, 35, 124-131. [CrossRef] [PubMed]

44. Wessely-Szponder, J. The Influence of TNFalpha and IL-8 on Secretory Action of Neutrophils Isolated from Heifers in the Course of Bovine Respiratory Disease. Acta Vet. Hung. 2008, 56, 187-196. [CrossRef] [PubMed]

45. Johansson, C.; Kirsebom, F.C.M. Neutrophils in respiratory viral infections. Mucosal Immunol. 2021. [CrossRef]

46. Zinicola, M.; Bicalho, M.L.S.; Santin, T.; Marques, E.C.; Bisinotto, R.S.; Bicalho, R.C. Effects of Recombinant Bovine Interleukin-8 (RbIL-8) Treatment on Health, Metabolism, and Lactation Performance in Holstein Cattle II: Postpartum Uterine Health, Ketosis, and Milk Production. J. Dairy Sci. 2019, 102, 10316-10328. [CrossRef] [PubMed] 